\title{
Tagetes Minuta Formulation Effect Sitophilus Zeamais (Weevils) Control in Stored Maize Grain
}

\author{
Parwada Cosmas", Gadzirayi Christopher, Karavina Charles, Kubiku Friday, Mandumbu Ronald, \\ Madumbu Belta. Z
}

Department of Agriculture, Bindura University of Science Education, P Bag 1020 Bindura, Zimbabwe

\begin{abstract}
The research was carried out at Chaminuka Training Centre in Mt Darwin district of Zimbabwe. Maize producers in the rural areas are challenged by storage pests particularly the Sitophilus zeamais. Affordable and readily available protectants are needed. A common weed, Tagetes minuta, was assessed for its potential to control Sitophilus zeamais. This provides a sustainable and degradable pesticide to the poor farmers. Maize grain samples arranged in a complete randomized design (CRD) were infected with 32 weevils each. The research was run for 8 weeks with the objectives to determine the efficacy of varying forms of Tagetes minuta on Sitophilus zeamais and to establish the effect of Tagetes minuta on maize grain weight loss. Weevil counts were taken on fortnight bases to establish mortalities. Grain weight loss was assessed using the Thousand Grain Method (T G M). There were variations on treatments with varied forms. The ground Tagetes minuta had the highest effect on both weight loss and weevil mortality compared to un- ground Tagetes minuta $(\mathrm{p}=$ 0.001). It was concluded that the ground Tagetes minuta works through a wider spectrum by causing physical and physiological effects on the weevil resulting in mortalities.
\end{abstract}

Keywords Sitophilus Zeamais, Tagetes Minuta, Maize, Storage Pest, Mortality

\section{Introduction}

Maize is a staple food in Zimbabwe, and is widely grown by smallholder farmers who contribute about $50 \%$ to national production (Rukuni et al; 2006). Much of the maize produced in this sector is lost to weevil attack. Very little research has been done on the development of affordable organic pesticides which offer same control levels as synthetics to weevils. After harvesting, the grain needs to be dried to right moisture content of $12.5 \%$ (Wright, 1995) to avoid rotting in storage. High moisture predisposes grain to attack by bacteria, fungi, insects and other microbes (Golob 2000). Sitophilus zeamais is one of the pests of economic importance in stored maize. It is so devastating and is capable of multiplying to large populations causing tremendous damage to the grain. Insecticides are expensive and mostly out of reach of most smallholder farmers (Murdock and Kitch, 1997) so this call for cheaper alternatives.

A variety of pesticides exist in the form of contact formulations, and their use depends on storage system and affordability. These can be used before pest infestation is evidenced. Actellic dust ( $20 \mathrm{~g} / \mathrm{kg}$ pirimiphos-methyl

* Corresponding author:

crparwada@yahoo.com (Parwada Cosmas)

Published online at http://journal.sapub.org/plant

Copyright (C) 2012 Scientific \& Academic Publishing. All Rights Reserved
$(2 \% \mathrm{w} / \mathrm{w}))$ is the most used chemical to control weevils and moths by the small scale farmers.

In Zimbabwe, a number of botanical grain protectants are used to reduce weevil damages. These include Colophospermum mopane (Murdock and Kitch, 1997) leaves and Tagetes minuta. In other parts of Africa, wood ash from fires has been used as grain protectant (Stoll 2000). Some cob and millet heads keep well in kitchen soot (Golob, 2002). Though botanicals are being used, questions remain on their appropriate rates and forms which are effective against weevils and other storage grain pests.

Grain weevils are so destructive that a local solution has to be sort. In some cases, those farmers who get synthetic pesticides use low rates that offer no control to the weevils. The synthetic insecticides pose a health hazard to the users and may have some residual effects. Farmers view use of traditional remedies with mixed feelings but inference can be drawn from work done elsewhere on their effectiveness (Murdock and Kitch 1997). Farmers who have tried to use Tagetes minuta as an option lack the knowledge on appropriate forms. Use of Tagetes minuta, will provide a cheap and safe option for use in granaries. The weed leaves no residuals on the grain. It is therefore environmentally friendly.

On the other hand developing an appropriate use may enable its eradication from the fields. Coming up with the right form effective for weevils will take the farmers far in keeping their grain safe from damages. The heavy reliance 
on the synthetic insecticides has led to insect resurgence and resistance and has a negative effect on non target organisms (Duke et al, 2003). This has raised concern to search for environmentally friendly storage pest control measures.

The research aimed at assessing the effectiveness of different forms of $\mathrm{T}$. minuta in controlling Sitophilus zeamais on stored maize grain

\section{Materials and Methods}

\section{Site Description}

The project was carried out at Chaminuka Training Centre in Mt Darwin South Zimbabwe. Chaminuka lies in agro-ecological region IIb which receives an average of $600 \mathrm{~mm}$ of rainfall and a temperature range of $20-30 \mathrm{oc}$ on average annually. The area has mixed tree vegetation dominated by Musasa and Acacia. The area is surrounded by small scale resettled farmers who are into maize production, and has red soils with various weed species, such as Tagetes minuta, Amaranthus hybridus, and many other narrowed leaved and grass weeds.

\section{Experimental Design}

The experiment was laid out in a complete randomized design (C R D) with four treatments that were ground material of Tagetes minuta, unground material of Tagetes minuta, Actellic dust (Synthetic), and untreated grain. The experiment had three replicates.

Table 1. Description of treatments

\begin{tabular}{|c|c|}
\hline Treatments & Description \\
\hline T1 & Ground Tagetes minuta \\
\hline T2 & $\begin{array}{l}\text { Actellic dust (Synthetic } \\
\text { pesticide) treated grain }\end{array}$ \\
\hline T3 & Unground Tagetes minuta \\
\hline T4 & Untreated grain (control) \\
\hline
\end{tabular}

\section{Experimental Procedure}

SC 513 maize seed variety was used in the experiment since it is the most commonly grown in the area of study. The grain was weighed into $500 \mathrm{~g}$ samples and placed in a freezer for two days to kill all residual weevils. The grain was sieved to remove all dirt and broken particles. The cleaned grain samples were put into small cut sacks covered with tiny netting to avoid weevils from escaping.
Thirty two weevils were introduced into each sack after 48 hours when the grain had achieved equilibrium moisture content. Seventy five grams of Tagetes minuta were used for both ground and unground treatments. Five grams of Actellic dust were used basing on proportionate calculations. No sexing of weevils was done as female and male presence was inevitable, as was case with other experiments done by Chinwada and Giga, (1997) on bean bruchid and the larger grain borer.

\section{Data Collection}

Two days after setting the experiment, physical weevil counts were done to check if there were no weevils that had escaped. Dead weevil counts were done at two week intervals. Grain loss assessments were done using Thousand Grain Method (TGM). Twenty grains per sample were weighed to get the initial TGM then ground and heated at $105^{\circ} \mathrm{C}$ to determine gravimetric moisture content and re-weighed to obtain the final TGM. The two values of TGM were then used to calculate the weight loss as follows:

TGM $=$ Initial TGM - final TGM/Initial TGM $* 100$

Recordings were done during the day when weevils are most active. The weevil counts data was given as percentages to compound averages on the mortalities.

\section{Data Analysis}

ANOVA was performed $(\mathrm{p}<0.001)$ on the percentage weight loss and weevil mortality using GESTAT (2002) package. Version 6.0

\section{Results and Discussion}

Table 2. Efficacy of Tagetes minuta on Sitophilus zeamais mortality

\begin{tabular}{|c|c|c|c|c|}
\hline \multirow{2}{*}{ Treatment } & \multicolumn{4}{|c|}{ Cumulative number of dead weevils at: } \\
\cline { 2 - 5 } & $\begin{array}{c}14 \\
\text { days }\end{array}$ & 28 days & 42 days & 56 days \\
\hline ground Tagetes & & & & \\
minuta & $62.6 \mathrm{a}$ & $93.8 \mathrm{a}$ & $100 \mathrm{a}$ & $100 \mathrm{a}$ \\
Actellic dust treated & $100 \mathrm{~b}$ & $100 \mathrm{a}$ & $100 \mathrm{a}$ & $100 \mathrm{a}$ \\
Unground Tagetes & $30.6 \mathrm{c}$ & $59.4 \mathrm{~b}$ & $77.1 \mathrm{~b}$ & $88.5 \mathrm{~b}$ \\
minuta & $15.6 \mathrm{c}$ & $24 \mathrm{c}$ & $30.2 \mathrm{c}$ & $37.5 \mathrm{c}$ \\
Untreated Grain & & & & \\
\hline Lsd & 18.13 & 11.54 & 9.56 & 9.53 \\
\hline P value & 0.001 & 0.001 & 0.001 & 0.001 \\
\hline
\end{tabular}

Means followed by same letter in a column do not statistically differ ( $\mathrm{p}<$ $0.001)$

There were significant differences in weevil mortality among the treatments as shown in Table 2. The mortality ranged from $9-100 \%$ ( Table 2).

In the first 14 days, the treatment with Actellic dust recorded $100 \%$ mortality. This was followed by the ground treatment which started by having $62.6 \%$ and there was significant accumulative weevil mortality in the second fortnight of 93.8. At 42 days the efficacy of the ground Tagetes minuta on weevils was the same $(100 \%)$ with the synthetic. The unground treatment had a mortality of 30.6 which showed no significant cumulative differences. 


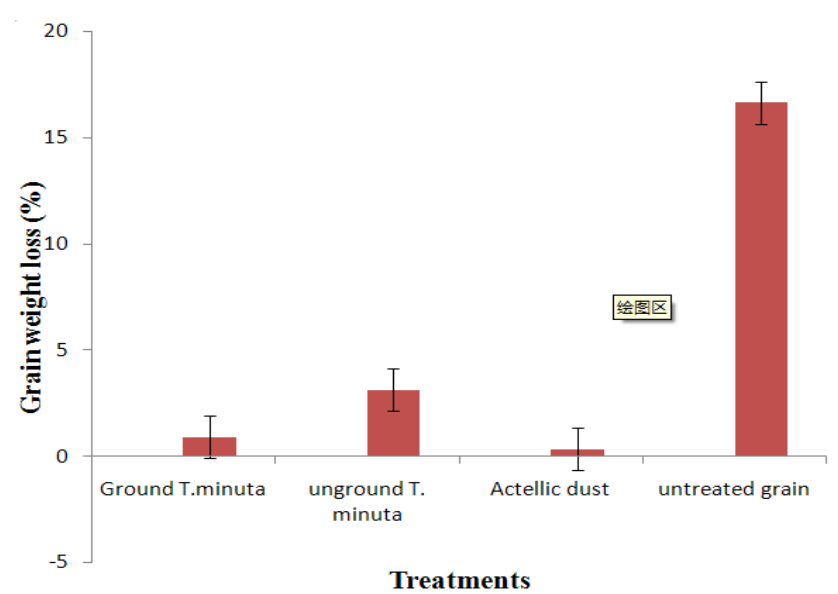

Figure 1. Efficacy of Tagetes minuta on Sitophilus zeamais control on grain weight basis

There was significant $(\mathrm{p}<0.001)$ differences on weight loss among the four treatments, where weight loss varied from $0.35-16.64 \%$ (Figure 1). The damage to grain shown by weight loss was highest in the untreated grain. Ground Tagetes minuta showed insignificant differences $(p>0.001)$ to grain weight loss with synthetics.

\section{Variations in Weevil Mortality}

Results showed significant differences $(p<0.001)$ in weevil mortality over the 56 days. The efficacy of ground Tagetes minuta started slowly and increased sharply at 42 days. The untreated grain had the lowest weevil mortality as the insects were free to move and weevil mortality might have been due to disturbances other than any other cause. The untreated grain offered a free environment where the weevils suffered no developmental limitations hence the highest feeding rate. Synthetics recorded $100 \%$ weevil mortality showing that they are capable of eradicating weevils on stored maize. The trial with ground Tagetes minuta showed increased weevil mortality from Day 1 up to Day 56 and this could be due to increased surface area between the weevils and the botanicals. Ground dusts form had insecticidal effect work by inhibiting weevil movement or inducing desiccation (Birch 1984). In the unground treatment reduced weevil damage could have been a result of improper contact between the grain and the plant debris. In this case weevil had enough space to move and feed. This is in agreement with Casida (1990) when he proved that use of whole plant (Labitate) could not control bruchids in cow peas.

The use of unground whole plant had less effect when compared to the ground Tagetes minuta due to reduced surface area of reaction hence failed to act as a pesticide. This can be confirmed by results of similar experiments where unground Chenopodium ambrosioides failed to release its insecticidal effect on weevil (Bouda et al; 2001). Ground Tagetes minuta may have an antifeedant activity on the weevils. This is in support to Malik and Mujtaba (1984), who reported that ground C.ambrosiodes has antifeeding activity on Rhyzopertha dominica (Bostrichid beetles).
Research has shown that organic pesticides are widely used in East Africa on grain legume. For example in Eritrea, farmers use ash to treat chick pea. It was observed that the ash offered total control to bruchids and the same way Tagetes minuta can be ground to very fine dust to offer same results (Figure 1). The action of the ash is thought to be physical as well as physiological by causing injuries especially to newly hatched weevils (Khaire 1992).

The exposure of the grain to ground botanical increased weevil mortality (Casida, 1990). This was also observed in experiments done by Paez (1987) using ground Boldus leaves which had the highest weevil mortality as opposed to unground which reduced weevil mortality (Table 2). The high weevil mortality by the ground botanicals showed the complexity of the physical effect of the ground dust on weevils. The reduction in weevil survival by ground Tagetes minuta provides a basis for the objective use of traditional botanicals in grain protection. The results of the study demonstrated a possible scientific rationale for the incorporation of Tagetes minuta as a grain protectant.

\section{Variations in Weight Loss Due To Weevil Damage}

The results showed that grain weight loss can be $80-100 \%$ in a period of 56 days due to weevil damage if untreated. The treated grain had lowest weight loss and the loss could be moisture loss not weevil damage. This showed high efficacy in synthetics and ground Tagetes minuta on weevils. The ground Tagetes minuta could have acted by dehydrating and suffocating the weevil and also by reducing weevil movements. This mode of action by ground botanicals was reported by Hall (1990) in related experiments where he observed that dust botanicals impose desiccation to weevils besides insecticidal effects. Many dusts have been shown to be very effective on weevils for example cypermethrin $1 \%$ dust which is used to treat grain in storage (Chiu, 1989). The dusts might as well act by reducing relative humidity on the surface of grain inhibiting egg laying and larval development of the weevils. This is in agreement with Aslam and Suleman (1999) when they showed that wild sunflower dust is effective on controlling weevils on stored grain.

\section{Conclusions and Recommendations}

The results showed that ground Tagetes minuta is very effective in killing weevils and also reduced grain weight loss. The efficacy of ground Mexican was statistically the same with the synthetic pesticides. Therefore the resource poor farmers can use ground botanicals (Tagetes minuta) in controlling maize weevils as they may not afford to buy synthetics. Farmers may integrate the synthetic pesticides and botanicals for effective control of the weevils.

\section{REFERENCES}


[1] Aslam M and Suleman C (1999) Postharvest Management of stored farm commodities, The International Xi 53. 5

[2] Birch L C (1984). Two strains of Calandra oryzae L (Coleoptera) Australian Journal of Experimental Biology and Medical Science, 22:271-275

[3] Bouda H, Tapondjuo A L, Fontem D A, Gumedze , (2001) Effects Of Essential Oils From leaves Of Agerutum conyzoide ,Lantana camara and Chromolana odorata on the mortality of S. zeamais. Journal for Stored Food Products Research 37. 103-105.

[4] Casida ,J H (1990) Pesticide and alternatives: innovative chemical and biological approachies to pest control. p11-22 Amsterdam ,Elsevier

[5] Chinwada P and Giga D P (1997) Traditional seed protectants for control of bean bruchid.Tropical science. 44. 311-319

[6] Chiu S. F (1989) Recent Findings on Meliaceae and other promising botanical insecticides in China, Journal of Plant Insects and Disease Protection, 36. 310-319

[7] Duke.S.O, Baemson .S. R and Dayan. A. M (2003) Research on natural products for pest management, US department of agriculture, Agriculture Research Services, Sci Sa, 708-717.

[8] Golob. P (2000) A practical assessment of food losses sustained during storage by smallholder farmers in the Shire Valley Agriculture Development area of Malawi, Department of the Tropical Products Institute, Slough G 138 p 32
[9] Golob. P (2002) Protection of farm stored grains against infestation by horn species in Tanzania, Journal of Stored Products, Research. 29. 210-299

[10] Hall. D. W (1990) Handling and storage of food grains in the tropical and subtropical areas, F A O. Rome Italy

[11] Khaire. B. P (1992) Influence of phenotypic characters of chickpea cultivars, their susceptibility to weevils, Legume Res 54 -56. Natural Resources Institute, U K

[12] Marlik. M M and Mujtaba Naqvi, S H (1984) Screening of some indigenous plants repents or antifeedants for stored grain insects. Journal of Stored Products Research 20, 41-44.

[13] Murdock. L L and Kitch. C (1997) Post-harvest storage of cowpeas in Sub- Saharan Africa ,Bulletin of Entomological Research 52,635-645

[14] Paez A. (1987) Plants used for the control of insects pests on grains in parts of North West Highland savanna Zone of Cameroon, Science Agronomiques Department press, Cameroon

[15] Rukuni M ,Tawonezvi P ,Eicher C (2006) Zimbabwe's Revolution Revisited, Sable Press PrivateLimited ,Zimbabw e

[16] Stoll G (2000) Natural crop Protection in the Tropics Verlag Joset Margrat. Scientific Books, Germany

[17] Wright M A P (1995). Loss assessment for stored products in the Tropics: Appropriateness Understanding 